\title{
Correction to: Resistance to demethylation inhibitors in Cercospora beticola, a pathogen of sugar beet in Japan, and development of unique cross-resistance patterns
}

\author{
Miyuki Kayamori $(\mathbb{D} \cdot$ Alisa Zakharycheva $\cdot$ Hiroki \\ Saito $\cdot$ Ken Komatsu 1
}

Published online: 12 February 2021

(C) Koninklijke Nederlandse Planteziektenkundige Vereniging 2021

\author{
Correction to: Eur J Plant Pathol \\ https://doi.org/10.1007/s10658-021- \\ 02219-6
}

This erratum is published as vendor overlooked author corrections on Page 5,"the upper left, subsection "Cross resistant analysis", line 4, “. during proofing.

Original article has been updated.

\section{H. Saito}

Laboratory of Plant Pathology, Graduate School of Agriculture, Tokyo University of Agriculture and Technology (TUAT), 3-5-8, Saiwaicho, Fuchu, Tokyo 183-8509, Japan

\section{K. Komatsu $(\bowtie)$}

Institute of Global Innovation Research (GIR), Tokyo University of Agriculture and Technology (TUAT), 3-5-8 Siwaicho,

Fuchu 183-8509, Japan

e-mail: akomatsu@cc.tuatu.ac.jp 